\title{
Urbanization: Exploring Rural-Urban Migration, Conflict, and Anthropogenic Change in Colombia
}

\author{
Guibor Camargo, Andrés Miguel Sampayo, Andrés Peña Galindo, Francisco Escobedo, Fernando \\ Carriazo and Alejandro Feged-Rivadeneira* \\ Universidad del Rosario, Calle 12C \# 6-25, Bogotá, Colombia; guibor.camargo@urosario.edu.co (G.C.); \\ andres.sampayo@urosario.edu.co (A.S.); andresar.pena@urosario.edu.co (A.P.); \\ franciscoj.escobedo@urosario.edu.co (F.E.); fernando.carriazo@urosario.edu.co (F.C.). \\ * Correspondence: alejandro.feged@urosario.edu.co.
}

\begin{abstract}
Anthropogenic change is generally associated with population growth, land use change, and changing economies. However, internal migration patterns and armed conflicts can also be key drivers behind these anthropogenic change and demographic change processes. To better understand this dynamic, we explore the spatial relationship between forced migration due to armed conflict and changing demographic factors in Colombia; a country with a recent history of 7 million internal migrants. First, we spatiotemporally analyzed the relationship between anthropogenic and demographic change due to forced migration from internal armed conflicts using remote sensing to measure anthropogenic change during 1984-2018 and we then used statistical and spatial analyses of demographic data. We found that anthropogenic change is significantly and positively related with increased rural-urban migration. Results show that interregional expulsion is also negatively associated with such anthropogenic change. Indeed, different regions anthropogenic prints have had different sensibilities towards forced migration, and across different time periods. Findings are then used to discuss how social and political phenomena such as armed conflict can have significant effects on the dynamics and trajectories of humans and territories in countries such as Colombia.
\end{abstract}

Keywords: Demographic growth; Displacement; Remote Sensing; Forced Migration; Urban sprawl; Mobility.

\section{Introduction}

The growth of the world's urban population is one of the most influential phenomena in terms of the earth's sustainability as it is associated with global change that is affecting not only our environment, but climate as well [1-3]. One of these anthropogenic changes, urbanization, has been documented as being one of the most influential forces in creating novel ecosystem and plant and animal assemblages [4,5]. Socioeconomically, anthropogenic change is the main cause of contemporary epidemiological transitions [6], and has been a result of, and influenced, changes in land use and economic systems $[7,8]$. Indeed, the transition of a society as part of the industrialization and post-industrialization transition processes drive these economic shifts in the dynamics of labor, land, and capital and an eventual reduction in the demand for agricultural labor $[7,8]$.

Recent theories and literature describing this urbanization phenomenon have been primarily from North America and Europe; however, there is less information explaining urbanization and industrialization phenomena in other regions of the world $[9,10]$. Additionally, socioeconomic factors are often the principle reasons for the migration of people across regions and boundaries 
while other factors such as environment or political perception have been reported to play a lesser role in urbanization in many regions [11] (p. 19). Another direct factor can be social and political instability caused by armed conflicts between states as well as internal conflict within a state that causes the breakdown of governability and subsequently can trigger rural-urban migrations [12].

Studies of this intraregional, or within nation, migration caused by armed conflicts generally consider the status of these migrants as refugees while others refer to them an internally displaced [13]. [14] argues that the treatment of people, for each of these cases differs according to other sources of information. For example, [15] defines these internally displaced persons (IDP) as, "Persons or groups of persons who have been forced to flee or be homes or places of habitual residence as a result of, or to avoid, in particular, the effects of the armed conflict, situations of generalized violence, violations of human rights or natural disasters". The author's definition also refers to migrants who do not cross internationally recognized borders. In fact, by 1982 there were 10 refugees for every displaced person, and in 2006 there were 5 displaced persons for every 2 refugees [16]. [17] also highlights the cases of Darfur, Nepal and Colombia as examples of intrastate wars that have caused notable increases in IDPs. Since 1990, the number of victims of forced displacement - within the States - has been higher than that of refugees, but the gap has increased in the second decade of the 21st century [18]. [19] points out that displacement -forced or not- shapes the structure of relationships between the Global North and South.

In Colombia, displacement of people due to violence has affected 90 percent of the countries' municipalities either by expelling or receiving populations [8]. Such IDPs are in a greater degree of vulnerability due to loss of land, homes, and employment opportunities [20]. By the middle of the 20th century, Colombian municipalities such as Quibdo, Sincelejo, and Florencia had IDP rates between 20-26\% [8] (2005), and it was medium-sized cities that received the equivalent to $20 \%$ of their population in just a few years [21]. Conversely, some of Colombia's municipalities lost more than $50 \%$ of their population due to the forced migration and $10 \%$ lost nearly $25 \%$ of their population [22].

The principal cause of IDPs are exposure to most types of violent events, with the exception of bank robbery. In particular, the expulsion of rural population from areas of conflict to achieve multiple objectives such as acquiring land tenure and resources, for example, is a recurring tactic among armed groups [23] [24]. The lack of governability or the absence of the state, its institutions, services, and security they provide also contribute to the migrations of IDPs [25]. For example, Colombian paramilitary forces such as the Autodefensas Unidas de Colombia (AUC) caused between $57 \%$ and $63 \%$ of recent IDPs, while Guerrilla groups $12-13 \%$, and the remaining by other unidentified groups as well as the State [26].

\subsection{A brief history of Colombia's armed conflict.}

In the following section to better contextualize our study, we briefly explain the armed conflict in Colombia beginning in the 1980s. According to [27] during the thirteen years that elapsed between 1968 and 1982, FARC activism was barely relevant, with an average of 1.6 armed shots on rural populations and two ambushes per year. Thus, prior to 1982, the year in which the VII conference is held, overall, the FARC was a militarily weak guerrilla that did not exceed 1000 men (

Figure 1). The VII FARC conference is important in that is marks a milestone in the guerilla's strategy. In addition to adding to its name the acronym "EP" (people's army), the guerrilla organization adopts a "new way of operating" (NFO), specifically a military doctrine characterized by an escalation in the confrontation against the State, moving from the war of guerrillas (hit and run), to the war of movements. This new form of operations translated into noticeable defeats against the Colombian Military Forces, as well as a strengthening of the guerrilla force doubling 
their number in operational groups or fronts from 9 to 18 and thus reaching a greater territorial presence [28].

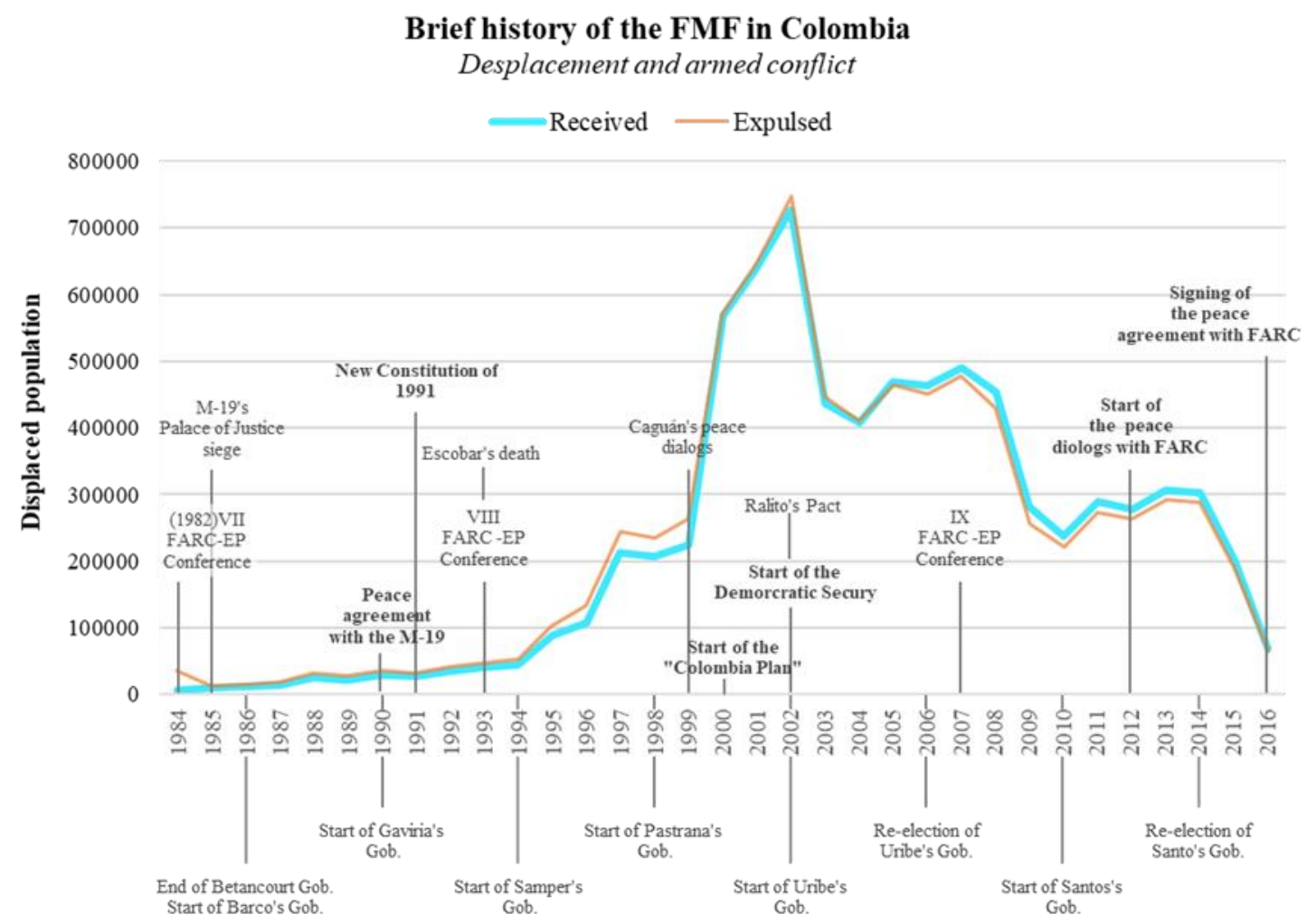

Figure 1. Brief history of the FMF in Colombia.

At the same time, the early 80's meant a growth of several guerrilla groups besides the FARC. New guerrillas emerged as the armed movement of indigenous origin, Quintin Lame and the Revolutionary Workers Party (PRT). Other previously consolidated movements are strengthened. Such is the case of the Popular Liberation Army (EPL), the National Liberation Army (ELN) and the M-19 movement. Later, towards the end of the decade, these groups will constitute a cohesive body known as the "Simón Bolívar Guerrilla Coordinator".

Another armed group, the M-19 guerrilla movement, was founded in the 1970s and was characterized by enhancing media actions such as the robbery of the sword of Simón Bolívar (1974); the theft of considerable armament from the army (1978); the kidnapping of the embassy of the Dominican Republic (1980), and the assault on the courthouse (1985). On November 6 1985, 70 members of the M-19 seized the congressional palace with 400 people inside. The government's response was direct consisting of a frontal and armed retaking that left 150 casualties including judges, civilians and guerrillas [29].

In 1984, President Belisario Betancur began a peace process with the FARC guerrillas known as the La Uribe agreements. A truce is decreed between the guerrilla side and the Colombian State, resulting in the creation of the Patriotic Union political movement, which wins positions in legislative elections and local governments. According to military intelligence, the FARC did not stop growing during the truce: they went from having 1,500 members in 1983, to doubling in 1985, reaching more than 3,500 men spread over 33 fronts [27]. 
By the end of the 80s, the State is in a convulsed war that takes place on different fronts: First, the breaking of the dialogues of La Uribe, meant the return of the FARC as an enemy, this time strengthened, as well as the parallel operation of the other guerrilla groups, (with the exception of Quintin Lame and the M-19 which initiated peace processes). Secondly, the rise and pressure of drug cartels, coupled with the political violence represented. In the murder of political candidates and members of the government, the Barco government initiates a direct confrontation against drug trafficking, especially against the Medellín cartel [30].

In this ongoing series of armed conflicts, coupled with constant corruption scandals and the murder of political candidates, a widespread clamor is brewing to generate profound changes in the Colombian society and political system. This clamor was channeled by the student movement through the phenomenon known as "seventh ballot": a citizen action that consisted of introducing an additional ballot in the 1990 legislative elections with the demand to reform the Current Constitution since 1886. Thus, The National Constituent Assembly emerges with the participation of various social sectors, resulting in the construction of a new Political Constitution in 1991 [30].

At the same time, at the beginning of the 1990s, different paramilitary groups and private armies emerge as a response from drug traffickers, businessmen, ranchers and the same State in response to the growing strengthening of guerrilla groups which used extortion and kidnapping as sources of financing. In 1993, the FARC-EP held its VIII conference, focused on the construction of an army with the ability to strike strategic coups to the State, for this, they adopted the creation of regional blocks and joint command, as well as the urbanization of the conflict through of militias [31]. The strengthening of the FARC-EP is evident, for 1991 they had 48 fronts (at the end of the decade this figure would increase to 62) [27].

The pace of the war intensifies in the second half of the decade, on the one hand, the different paramilitary groups are strengthened by unifying in 1997 in a single block called "United SelfDefense Forces of Colombia" (AUC) thus disputing territorial control and drug trafficking routes These paramilitary groups used war strategies to generate panic and anxiety in civil society (See Basta YA report), on the other hand, guerrilla groups, especially the FARC-EP take advantage of the political situation of delegitimization of the government of Ernesto Samper (1994 -1998) to gain greater territorial control and increase their offensive actions to populations (some with up to 1,200 combatants) moving to war of movements [27]. In the words of [31]:

"The successes were such that, in the United States, both the Defense Intelligence Agency, and the International Institute for Strategic Studies, came to affirm that the army was losing the internal war and that at that rate they anticipated the defeat in five years "

Both armed phenomena (paramilitary and guerrilla) affect the increase in forced displacement, reaching its peak in 2002, when The Plan Colombia begins (see Figure 1).

The Plan Colombia: In 1998, the conservative candidate, Andrés Pastrana, won the elections amid a social clamor for a negotiated solution to the armed conflict. Thus, the Caguán negotiating table is installed in his government: a large area of more than $42,000 \mathrm{~km} 2$ cleared of military presence. Finally, the talks fail in 2002, however, this period of truce allowed a significant strengthening for both the guerrillas by allowing them to relocate their members and advance their siege strategy to Bogotá reaching 18,000 combatants over 70 fronts [32], as for the Colombian State when negotiating huge technical and financial resources by the United States through the "Plan Colombia".

The Plan Colombia plan, negotiated in the government of Andrés Pastrana, and launched in the first government of Álvaro Uribe, meant a huge injection of capital from the United States, in order to modernize the Colombian Army, thus, Colombia came to occupy the third place in receiving American aid after Israel and Egypt [31]. Initially, Plan Colombia had a social investment objective 
in order to reach a state of social stability in Colombia, however, as mentioned [32], once the US counterpart began, and especially with arrival George Bush, the Plan becomes preponderantly military at a cost in that period of more than 1900 million dollars [33].

For this same period, the paramilitaries (AUC) increase their military power, reaching 8,000 men between 1998 and 2002 [32]. In addition, the year 2002 represents a turning point in the history of the Colombian armed conflict. The first mandate of Álvaro Uribe begins; whose main flag was the strategy of "Democratic Security", a government policy aimed at ending the internal enemy represented in the insurgent groups through military victory. Uribe's promise to end the guerrillas in four years was not possible, which led the Government to propose constitutional reforms, especially tending to the possibility of presidential re-election.

Thus, in 2004 the Congress of the Republic approves mostly the presidential reelection, being used this condition by the then president Álvaro Uribe who is reelected in 2006, this time exponentially increasing the heading for security and defense. During the 2006 - 2010 period, public spending on defense represents more than $5 \%$ of GDP, more than double what the OECD countries used at the time [32]. This investment, coupled with the overflow of paramilitary groups meant a rhetoric and practice of annihilating the enemy, which resulted in an immeasurable violation of Human Rights. According to data from CINEP [34] (2010), during the period from 2002 to 2009, a total of 12997 violations of human rights and IHL were recorded, of which 5486 attributed to paramilitaries, 4358 to the Public Force, 2507 to the FARC and the rest to Other armed actors. These figures converge with the cases of displacement recorded in the same period (see Figure 1).

In 2009, at the end of his second government, Uribe tried again to reform the constitution in order to allow a second re-election, however, it was repealed by the Constitutional Court. Consequently, Uribe presented his then Minister of Defense, Juan Manuel Santos, as the successor of his policies, who won the victory by a wide margin.

\subsection{Remote sensing}

Remote sensing technologies can provide the opportunity to monitor these land use and land cover changes such as urbanization and can also be used to better understand the spatial dynamics of anthropogenic phenomena [35]. Anthropogenic phenomena that have been described in past literature on the interaction between greenness and sociodemographic variables [35] [36], residential desirability and social structure [35,37,38], poverty and inequality $[35,39,40]$, well-being [35,41], and sociodemographic spatial distributions [35,42,43]. The use of remote sensing and empirical models to describe demographic and socio-economic phenomena is also well documented [35,44]. In particular, the increased availability of sensors, satellite imagery and increased resolution has facilitated the study of processes such as urbanization, land-use and landcover change, population densities, crime, housing markets, and many other problems associated with urban and regional planning [35,45-49].

For example, high resolution images have been used to detect temporal urban changes at the sale of individual buildings and combinations of Landsat, SPOT- 5 and Synthetic Aperture Radar images have been used for single and comparative studies of urban growth particularly in Chinese cities [35,48,50-52]. Night-time satellite imagery has also been used to study urban and peri-urban growth and its dynamics with human densities, economic activities and pollution [35,50-54]. Remote sensing is also being used to better measure, verify and understand violent conflict particularly in inaccessible, dangerous areas lacking data [55] .

\subsection{Aims and Objectives}


Given the lack of information in how conflict, economies, and demographics drive the movement of IDP to cities, we explored the relationship between forced displacement and anthropogenic change in Colombia. Our aim was to understand anthropogenic change in Colombia and how conflict influenced internal migration and subsequent demographic changes in cities. Accordingly, our objectives were two-fold. First we use remote sensing to measure national-level anthropogenic change over a period of 20 years marked by armed conflict. Second, we analyzed how the spatial dynamics between anthropogenic change and forced displacement were driven by conflict and other demographic factors during this analysis period. Such an approach can be used to better understand the political, demographic and economic drivers of anthropogenic changes on land cover and the influence of forced migration and demographic changes.

The recent and current socio-political context in Colombia presents a unique opportunity to explore the effects of migration on urbanization in a country with one of the world's largest documented population of IDPs. Below, we combine remote sensing data, migration and armed conflict victim along with spatial and statistical analyses to explore the association between anthropogenic change and internal migration. We propose that this context and approach to study the drivers of urbanization and rural-urban migration of people is novel and differs from other previous studies [56-58].

\section{Materials and Methods}

\subsection{Study area}

According to Ocampo [59] (2015) between 1993 and 2005, the population of Colombia's municipal capitals grew at a rate of $2 \%$ per year, while the rural population decreased at the rate of $0.09 \%$. The causes for this reduction in the population are associated, on the one hand, with a fall in fertility rates with some particularities associated with adolescent fertility and an increase in migration to cities by the youngest population. The author reports that the influence of the armed conflict versus migrations due to employment opportunities on this growth was unknown [59].

\subsection{Spatial analysis}

As shown in Figure 2, in the phase of the first analysis we used twelve different nightlight rasters from the Defense Meteorological Program Operational Linescan System (DMSP OLS - Nighttime Lights Time Series Version 4 raster data set). Image and Data processing by NOAA's National Geophysical Data Center. DMSP data is collected by the US Air Force Weather Agency. The rasters selected from DMSP OLS, where part of the avg_vis band, which contains unfiltered mean values of visible light. These raster data contain the average light from two years (ex: the raster named 1992, contains the averaged nightlight raster value between 1991 and 1992), which means that by selecting twelve raster files from this data set we were working with 24 years. Figure 2 shows the data processing implemented to generate the following variables used in our analyses: Average Anthropogenic Change (AAC), the Anthropogenic Print Spatial Expansion (ApSE) and the Anthropogenic Print Spatial Contraction (ApSC) for Colombia from 1991 to 2013.

\subsubsection{Anthropogenic change vs. urbanization}

We decided to focus on anthropogenic change and use Nighttime to measure it for several reason: 1. Imagery is available for our period of interest, 2. Nighttime imagery has been used to appropriately describe population flows, as opposed to land-use change measured by classification of multi-spectral satellite imagery [35,50-54]. Multiple studies show that change in Nighttime patterns can be adequately used to study human activity, with some limitations to keep in mind: 1 . not all observed increase in light values should be interpreted as urbanization. Other anthropogenic processes, such as mining, will be detected by nighttime satellite imagery. We consider this a virtue 
of our method, since we are interested in describing population flows. We decided to use the term anthropogenic print to denote changes in nighttime satellite imagery, and one common anthropogenic change is urbanization. Results should be interpreted with caution in this regard. To better describe the differences between anthropogenic change and urbanization in Colombia from our dataset, we present a section where the main metropolitan areas of the country are described.

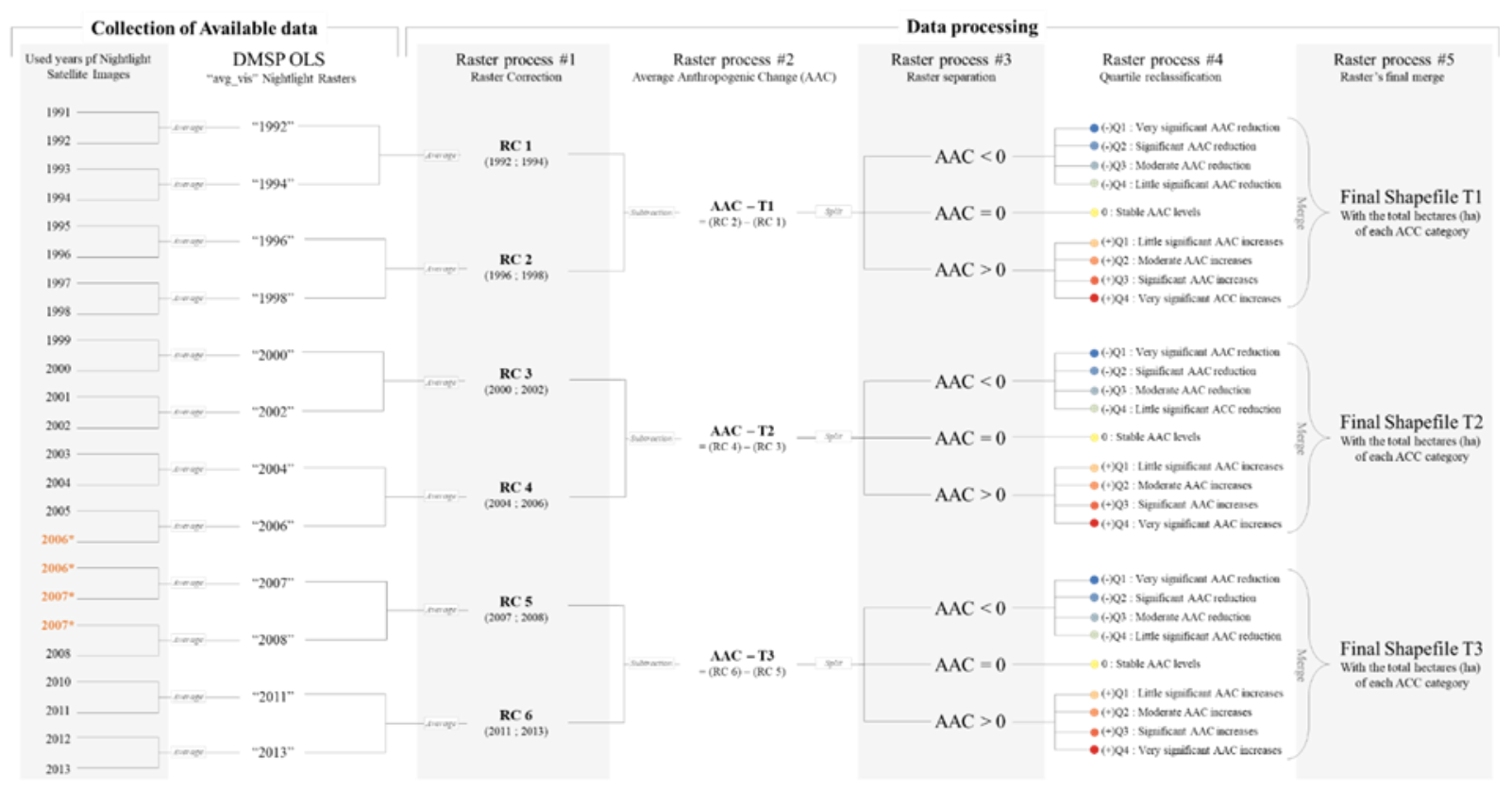

Figure 2. Data processes.

For our second analysis, we used Google Earth Engine and created 6 new corrected raster files (RC) from the average of two consecutive DMPS OLS files (raster process 1). We then averaged 4 different nightlight raster years to correct for climate variations or other possible inaccuracies such as cloud coverage, casual imperfections in the satellite image collection or non-permanent nightlight captures (such as fires). Next, raster process number 2 consisted in calculating using Google Earth Engine the AAC for three time periods of interest (1991-1998, 1999-2006 and 20062013), . To do so, we simply took the difference between different RCs as shown in Figure 2. The following equation 1 summarizes the composition of the AAC index.

$A A C=\Delta R C=R C_{T+1}-R C_{T}=\frac{\Sigma_{t_{+5}+8}^{t_{3}} \text { avg_vis }}{4}-\frac{\Sigma_{t}^{t_{+4}} \quad \text { avg_vis }}{4}$

AAC is a measure of the change in nightlight radiation between time periods made of 4 years each. These previous analyses explained how we built the AAC raster which we used to extract several municipal level statistics including: AAC's average, AAC's standard deviation, AAC's maximum and minimum values, etc. It is important to have into account that the statistics produced from the AAC index for every municipality were obtained from the values of each pixel located inside a municipality boundary. In this sense, the AAC is a changing luminance intensity index instead of a measure related to any type of change in nightlight's geographic extent.

Our third analysis, Raster process 3 consisted of splitting all AAC rasters into 3 new ones using ArcGIS software (version 10.5): one containing all the negative value pixels, which correspond to places where the intensity of nightlight had decreased; a second raster containing all the pixels with 
values near 0 , that referred to areas in which nightlight intensity had not changed; and finally a third raster with just the positive value pixels, which highlight the places where nightlight have increased. Then in raster process 4 , we independently used the positive and the negative rasters, and reclassify each into quartiles: in this way, when we re-grouped the three rasters for each time period, and transform it into a shapefile, as shown in rasters process 5 , we obtained a final database which classified all the national territory into 9 different categories as shown in Figure 3.
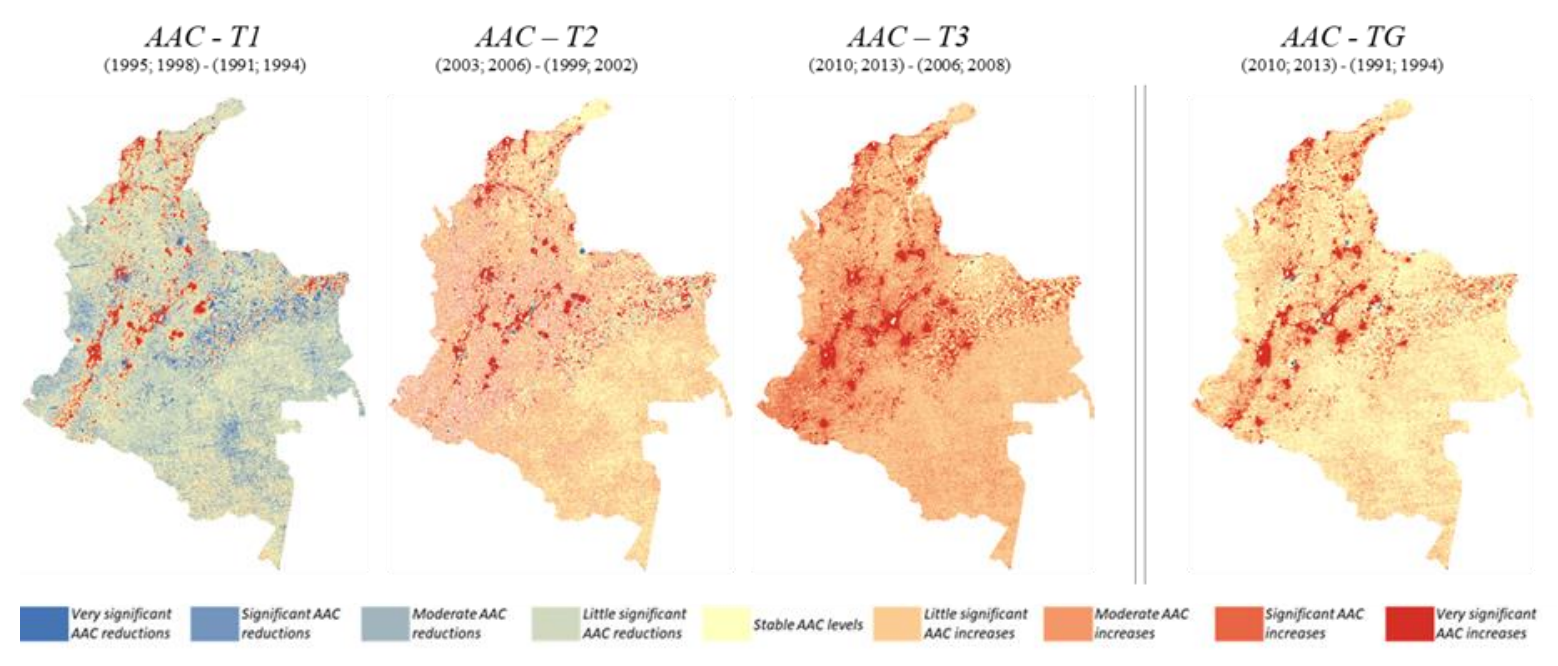

Figure 3. Visual representation of the spatial dataset used for the econometric analysis.

Finally, after defining the AAC and classifying all Colombia's surface in their corresponding intensity variations, we calculated the ApSE and the ApSC: calculating the geographic transformations that have occurred the last 20 years in the country. Both of these indice are designed to measure the expansion or contraction of the nightlight across geographic space. To perform this task, we calculate for each time period and municipality, the area covered by all the nine AAC categories (that where optioned from two a separated quartile ranks). Then, to calculate the Anthropogenic Print Spatial Expansion (ApSE), we took the area (in hectares) categorized into the last two positive quartiles of AAC (areas that in a specific time period suffer either significant AAC increases, or very significant AAC increases) and divided by the total hectares of each municipality. We then calculated the Anthropogenic Print Spatial Contraction (ApSC), by taking the area categorized into the first two negatives quartiles (areas that either suffer significant or very significant ACC reductions) and applied the same division mentioned above. The following equations 2 and 3 summarize both spatial indexes, and where i represents a municipality and $\mathrm{T}$ a time period:

$$
\begin{aligned}
& A p S C_{T}=\frac{H a_{i} \|(-Q 1)_{T}+(-Q 2)_{T}}{\text { Total Ha }} \\
& A p S E_{T}=\frac{H a_{i} \|(+Q 3)_{T}+(+Q 4)_{T}}{\text { Total } H a}
\end{aligned}
$$

Overall, AAC allows the identification of changes in nightlight intensity levels, but it does not reflect the geographic expansion of anthropogenic activity (such as urban expansion). Therefore, taking this variable as a proxy for spatial expansion could bias the statistical analysis. This is because there are some places with high changes in AAC levels but still do not suffer any 
significant changes related to the size of the anthropogenic print: this increments in nightlight intensity could be more related to densification process, electrification programs, or increases in electricity consumption. Nevertheless, the AAC index is a step needed to calculate and finally obtain the ApSE and the ApSC, which we then used in order to understand the spatial and geographic transformations of Colombia's anthropogenic print across time, and its relation with the social phenomena of forced migration.

We note that in our analyses we excluded the DMPS OLS rasters from 2010 and 2009, as both had important errors that could not be fixed. To compensate for this, as seen in Figure 2, we decided to iterate years 2006 and 2007 to skip the damaged referenced nightlight rasters. Also, we built a fourth time period (AAC - TG), that compares the first time period with the last $([2010 ; 2013]-$ [1991; 1994]). Finally, check Table 1 to look the final night-light values for each quartile a time period.

\subsection{Statistical Analyses}

As mentioned earlier, our focus was to understand and estimate the relationship between forced migration and urban expansion in Colombia. To do so, our analysis variable was "forced migration flow" (FMF), a metric accounting for percent population growth or decrease, due to forced migration for each municipality. We use the following formula to calculate this index:

$F M F_{T}=\frac{\sum_{t=1}^{8} \quad \text { Received population }-\sum_{t=1}^{8} \quad \text { Expulsed population }}{\text { Total population } t 8}$

Our main restriction was that we only count with 3 different time periods which restricted the opportunity to run panel base regression models. To compensate for this, we decided to run different types of cross section regressions simultaneously for every time period. In addition, for each ApSE time period, we estimate tree different FMF indexes: one that overlaps with the time period (0 lag), a second that takes 4 years within the ApSE time period and 4 years before, and a third one that calculates the FMF for 8 years before the intervention, as shown in the following figure:

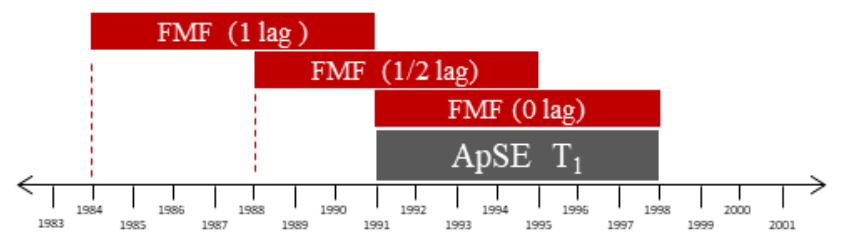

Other variables that we used, were the logarithm of the distance from each municipality to its corresponding departmental capital, the Demographic Bonus (DB) that refers to the demographic balance between the economically active population (between 15 and 65 years old) and economically dependent population (the rest of the population) for every municipality. We also added the demographic bonus squared to identify possible nonlinear behaviors. The percentage of the population living in the urban area for the beginning of each time period of ApSE was also added as a covariate, as well as the municipalities' percentage of deforested area from 2000 to 2017. Forced migration data was obtained from the Unique Registry of Victims (RUV), from the Colombia's Victim Unit. Demographic data (demographic structure and population size), was taken from the National Census of 1993 and 2005, and its corresponding statistical projections. The distance from each municipality to the department's capital was calculated using ArcGIS's Euclidian analysis, and finally the deforestation data was downloaded from Global Forest Watch 
raster dataset and after rendered to obtain municipal level data. The following table contains the summary statistics for the described variables:

Table 1: Summary statistics of all the variables used in the statistical analysis.

Summary statistics

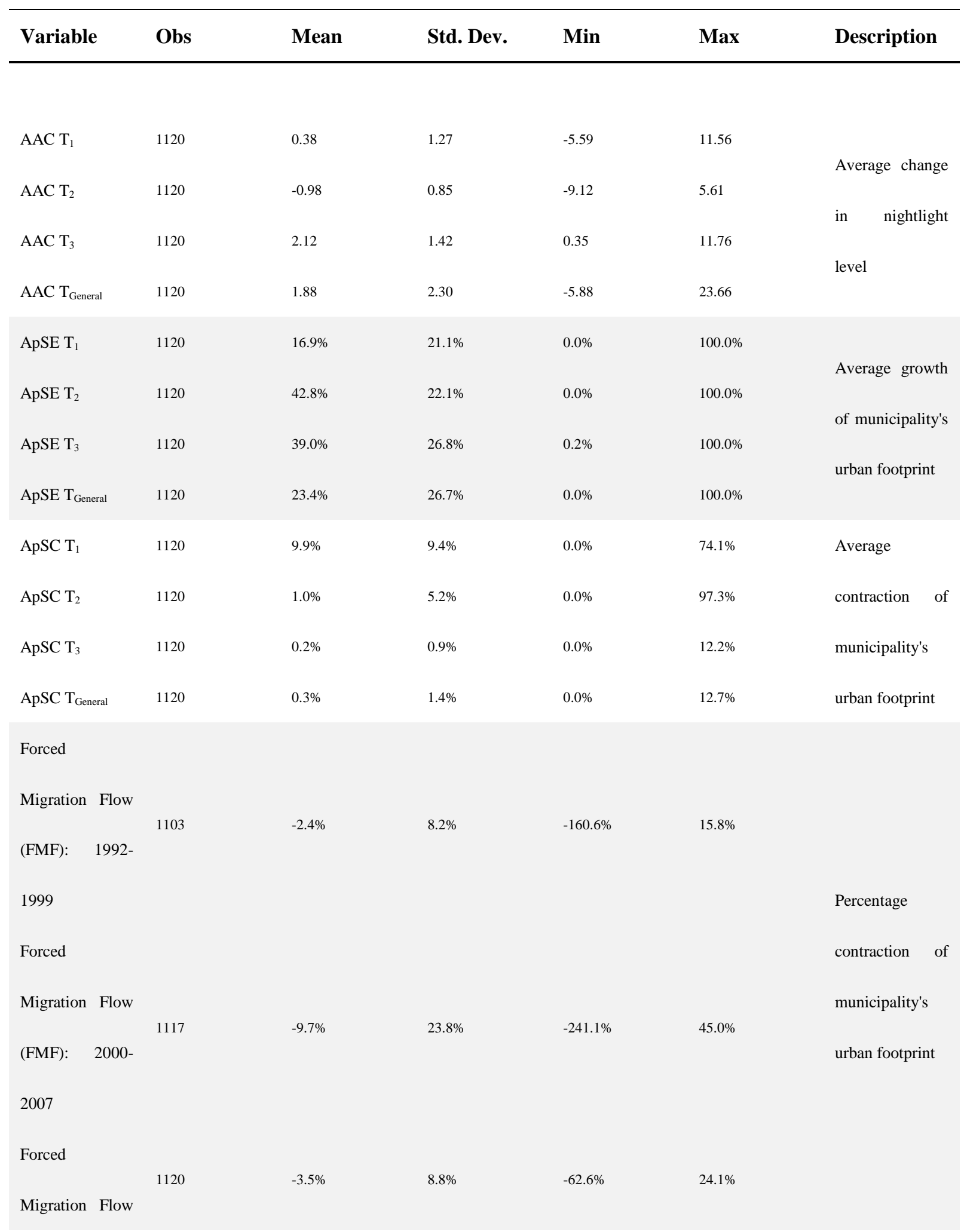


(FMF): 2007-

2014

Forced

Migration Flow

$\begin{array}{lllll}1120 & -14.7 \% & 32.9 \% & -326.4 \% & 58.8 \%\end{array}$

(FMF): 1992-

2014

Ratio between

Demographic

Bonus (DB)

1111

0.72

0.36

0.39

0.24

0.00

1.00

1999

$\%$ of urban

population in 1112

0.39

0.24

0.00

1.00

2000

$\%$ of urban

population in 1117

0.42

0.44

0.25

0.24

0.00

0.00

1.00

1.00 active and

dependent

population

Percentage of

municipal

population who

live in the urban

area

Distance

in

Distance to a

61.34

43.95

414.56

kilometers

to

Capital City

1.34

1.00 departmental

capital 


\subsection{Statistical models}

We used four different models to capture and analyze the relation between forced migration flow (FMF) and anthropogenic print expansion (ApSE). As mentioned before, we decided not to run panel regression analysis because of lack of several time periods of ApSE, taking into account the way we decided to build it. In this sense, we ran three cross section regressions per model, one for every time period.

The first model used was an Ordinary Least Squares (OLS) with an additional interaction between the demographic bonus and the demographic bonus squared. The second and third model where developed form a neighborhood square matrix $\left(\mathrm{W}=1041^{*} 1041\right)$, calculated by queen contiguity between municipalities. We decided to use queen contiguity instead of other types of weighting matrix, because we wanted to put special attention to conurbation and metropolitanization process between contiguous municipalities. For a broader description of neighbor matrix types, and modeling procedures we recommend reading [60-63]. The second model is a Durbin spatial error model [60], which permits the identification of the influence of unobserved factors of neighbor municipalities in the dependent variable of given municipality $i$, storing this effect in a scalar parameter $\mathrm{Q}$, often called lambda. The General form of the second model is:

$y=a+x \beta_{1}+u$

$\boldsymbol{u}=\boldsymbol{\rho}(\boldsymbol{W u})+\varepsilon$

The third model, is the Durbin model for spatial lag, which is used to capture the effect of the dependent variable (in our case ApSE) of neighboring units in the dependent variable of a given municipality $i$, storing this effect in a scalar parameter $Q$, often called "rho" [64]. The general form of the third model is:

$$
y=a+x \beta_{1}+\rho(W y)+u(7)
$$

Finally, the fourth model was a Geographic Weighted Regression (GWR) that allows for the capture of the heterogeneity of the coefficients for each regressor across space, as well as understanding local key parameters as the standard error and the adjusted r-square [65,66], and which general form is:

$y_{i}=\propto+\sum_{k=1}^{K} \quad \beta_{k i} x_{k i}+\varepsilon_{i}(8)$

With this last specification, we wanted to specifically analyze the heterogeneity of the relationship between FMFs and the expansion of the anthropogenic print (APSE). After analyzing the results from all the other models, we ran the GWR just with one lag over the FMF for every time period studied, as this type of construction seemed to be the one that better capture the effect of FMF over ApSE. The only difference with the other used model, is that the GWR excluded the squared demographic bonus to avoid multicollinearity. 
We ran 27 cross section models for the different periods of study, namely $\mathrm{T} 1=1992-1999, \mathrm{~T} 2=2000$ $2007, \mathrm{~T} 3=2007-2014$. The first set of cross sectional models includes estimations by OLS as a model of reference and two spatial models (Spatial-Lag and Spatial Error) to explore: 1) possible spatial correlation of the Anthropogenic Print Spatial Expansion (ApSE), the dependent variable and 2) Spatial Correlation of the random error in the regression. The cross sectional models we first explored assumes that the process of Anthropogenic Spatial Expansion does not occur simultaneously with the Forced Migration process but we rather assumed that it takes some time for the Urban Expansion to occur, once a municipality is exposed to migration flows. Thus, we first ran models with one temporal lag of the Force Migration Variable, our explanatory variable of interest. The temporal lag of one period encompasses an eight-year period. After checking for the goodness of fit among models we selected the cross sectional method with best goodness of fit. We then explored different temporal lags for the Migration Flow variable for the selected model.

We included in the regression model the Demographic Bonus variable to explore how the Labor Force composition may affect urban expansion. This variable is defined as the ratio of the active labor force in productive age (From 15 to 65 years) and the dependent population (population younger than 15 and older than 65). We assumed that the relationship between the Demographic Bonus and Urban expansion was not linear. The results suggest that this variable follow a U-shape relationship since the coefficient that accompanies the variable Demographic Bonus (DB) is negative and the coefficient that accompanies the Demographic Bonus squared is positive. This behavior of the coefficients was prevalent in the models where both parameters were statistically different from zero at all conventional levels. Initially, at low values of DB we have large values of urban expansion, as the productive population increases or municipalities have lower dependency, urban expansion also decreases until it reaches a minimum. Then, at higher levels of $\mathrm{DB}$, urban expansion starts to experience a steadily increase. The minimum DB occurs where $\mathrm{DB}=\left(-\beta \_1\right) /\left(2 \beta \_2\right), 1.81$ (Calculated from the Spatial Lag). The average of this threshold for the estimations where the $\mathrm{U}$ shape relationship was significant was 1.88 . This means that the model predicts that the urban expansion starts to increase on average when the active labor (productive workers) are approximately twice as much as the dependent population.

\section{Results}

\subsection{Regressions}

We found that the Percent of Urban Population variable is positive and statistically significant in all estimated models. This result indicates that as the urban area as a percentage of the total area of the municipality increases in the initial period, the urban expansion increases. This effect was stronger for the regression models that encompassed the period 1992-1999. A one percent increase in the urban area at the beginning of period 1992-1999, brings as a result an increase of $0.18 \%$ in the urban expansion.

The negative coefficient of the variable Distance to a Capital City indicates that the proximity to a large urban center induces to a larger urban expansion. This may be explained by the strong economic interactions that may occur between large urban nuclei and the surrounding municipalities that may trigger urban growth. The percentage of municipal area with forest loss was not significant.

The coefficient for the variable FMF, our variable of interest, suggests a positive and statistically significant relationship between anthropogenic urban expansion and forced migration flows. These coefficients are positive in all model specifications. However, the coefficients that accompany this variable are significant at all conventional levels in the OLS and Spatial Lag specifications but not for the Spatial Error Model (Table 2). Overall, the magnitude of parameter estimates is larger in the OLS model than in the Spatial Lag version. Interestingly, the magnitude of the coefficients 
decreases as the Time Period for the estimation increases. For example, in the Spatial Lag model, the coefficient of the forced migration variable for the estimation that cover the period 1992-1999 is 0.650 while the value of this coefficient in the period 2007-2014 is 0.086 . This result suggests that the effect of the lagged migration on urban expansion was stronger in the period when the armed conflict reached its pick in terms of displacement $(\mathrm{T} 1=1992-1999)$ and had the inertia of a period with strong violence triggered by guerrillas and drug traffic (Lag T1=1984-1992). 
15 of 28

Table 2. Anthropogenic Print Spatial Expansion (ApSE) regression analysis with one lag over FMF

One lag over FMF

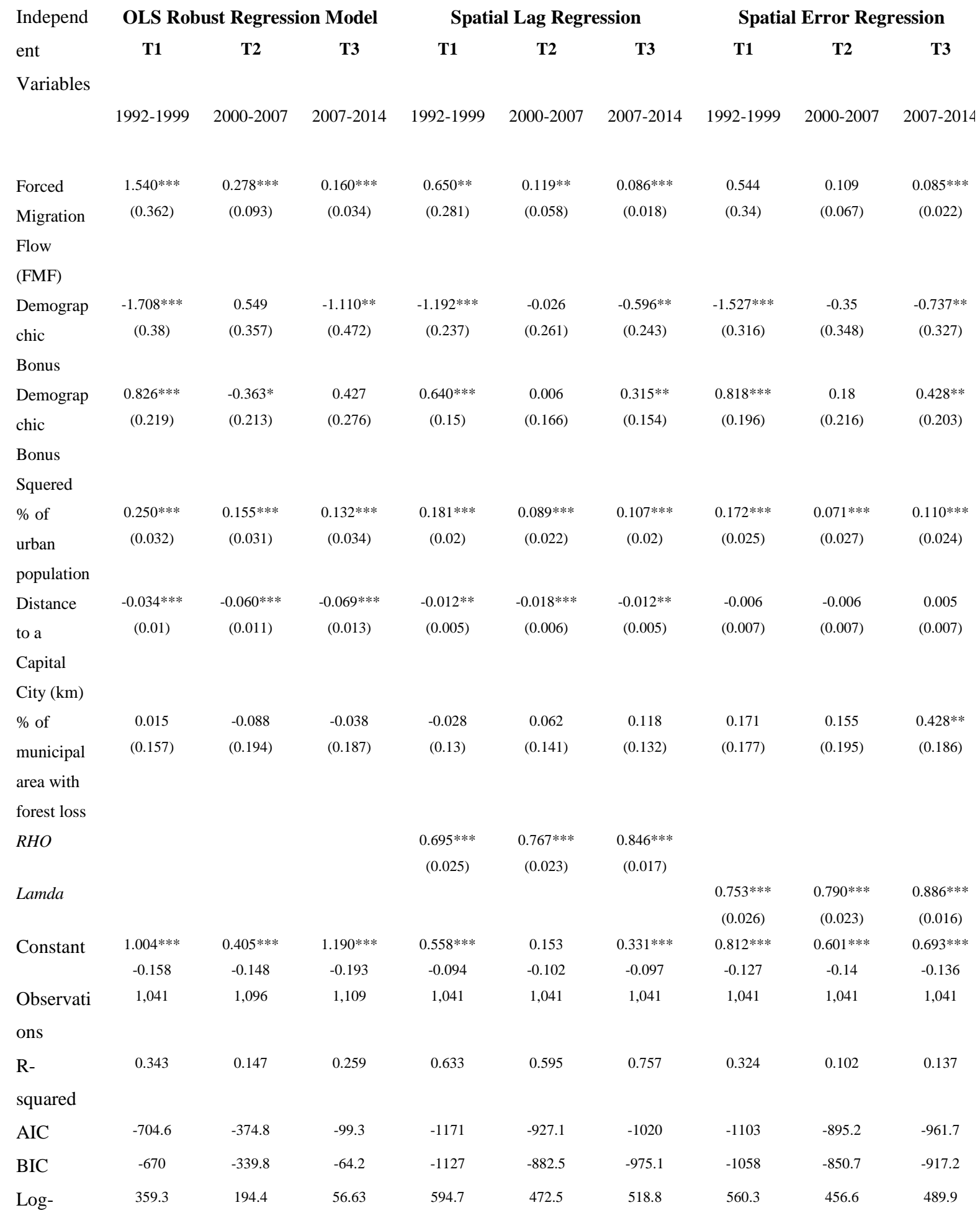

likelihoo

d 
When we examined the goodness of fit of all models, the results suggest that the Spatial Lag model better fits our data. Overall, the R2 statistic is higher in the spatial lag (i.e 0.757 for T3 in Spatial Lag) model compared to R2 of the OLS (0.259) or the Spatial Error models (0.137). The best goodness of fit of the Spatial Lag model is also supported by the higher values of the Log-likelihood for this specification compared to the Log-likelihood of the OLS and Spatial Error models (Table 2). Using the selected Spatial Lag model as a reference, we explored the effect of Flow Migration using different temporal lags, namely one lag, half a lag and no lag. (Table 3).

Table 3. Anthropogenic Print Spatial Expansion (ApSE) Spatial lag regression output

\begin{tabular}{|c|c|c|c|c|c|c|c|c|c|}
\hline \multirow{2}{*}{ Independent } & \multicolumn{3}{|c|}{ One lag over FMF } & \multicolumn{3}{|c|}{ Half lag over FMF } & \multicolumn{3}{|c|}{ Cero lag over FMF } \\
\hline & $\mathrm{T} 1$ & $\mathrm{~T} 2$ & $\mathrm{~T} 3$ & $\mathrm{~T} 1$ & $\mathrm{~T} 2$ & $\mathrm{~T} 3$ & $\mathrm{~T} 1$ & $\mathrm{~T} 2$ & r \\
\hline Variables & $1992-$ & 2000- & 2007- & 1992- & $2000-$ & 2007- & 1992- & $2000-$ & 21 \\
\hline & 1999 & 2007 & 2014 & 1999 & 2007 & 2014 & 1999 & 2007 & 2 \\
\hline Forced Migration & $0.650 * *$ & $0.119 * *$ & $0.086^{* * *}$ & $0.293^{*}$ & 0.032 & $0.199 * * *$ & 0.076 & $0.036^{*}$ & 0.2 \\
\hline Flow (FMF) & $((0.281)$ & $((0.058)$ & $(0.018)$ & $(0.163)$ & $(0.021)$ & $(0.035)$ & $(0.052)$ & $(0.02)$ & $(0$ \\
\hline Demographic & $-1.192 * * *$ & -0.026 & $-0.596 * *$ & $-1.195^{* * *}$ & -0.035 & $-0.631 * * *$ & $-1.213 * * *$ & -0.037 & -0.7 \\
\hline Bonus & $(0.237)$ & $(0.261)$ & $(0.243)$ & $(0.238)$ & $(0.261)$ & $(0.242)$ & $(0.237)$ & $(0.261)$ & $(0$ \\
\hline Demographic & $0.640 * * *$ & 0.006 & $0.315^{* *}$ & $0.641 * * *$ & 0.013 & $0.345^{* *}$ & $0.653 * * *$ & 0.016 & 0.2 \\
\hline Bonus Squared & $(0.15)$ & $(0.166)$ & $(0.154)$ & $(0.15)$ & $(0.166)$ & $(0.154)$ & $(0.15)$ & $(0.166)$ & $(0$ \\
\hline$\%$ of urban & $0.181 * * *$ & $0.089^{* * *}$ & $0.107 * * *$ & $0.183^{* * *}$ & $0.089 * * *$ & $0.097 * * *$ & $0.185^{* * *}$ & $0.087 * * *$ & $0.0^{\prime}$ \\
\hline population & $(0.02)$ & $(0.022)$ & $(0.02)$ & $(0.02)$ & $(0.022)$ & $(0.02)$ & $(0.02)$ & $(0.022)$ & $(C$ \\
\hline Distance to a & $-0.012 * *$ & $-0.018 * * *$ & $-0.012 * *$ & $-0.012 * *$ & $-0.018 * * *$ & $-0.010^{*}$ & $-0.012 * *$ & $-0.018 * * *$ & -0 . \\
\hline Capital City (km) & $(0.005)$ & $(0.006)$ & $(0.005)$ & $(0.005)$ & $(0.006)$ & $(0.005)$ & $(0.005)$ & $(0.006)$ & $(0$ \\
\hline$\%$ of municipal & -0.028 & 0.062 & 0.118 & -0.06 & 0.048 & 0.16 & -0.072 & 0.058 & 0 \\
\hline $\begin{array}{l}\text { area with forest } \\
\text { loss }\end{array}$ & $(0.13)$ & $(0.141)$ & $(0.132)$ & $(0.128)$ & $(0.141)$ & $(0.132)$ & $(0.128)$ & $(0.142)$ & $(0$ \\
\hline RHO & $0.695^{* * *} *$ & $0.767 * * *$ & $0.846^{* * *}$ & $0.698 * * *$ & $0.769 * * *$ & $0.843 * * *$ & $0.699 * * *$ & $0.768 * * *$ & 0.8 \\
\hline & $(0.025)$ & $(0.023)$ & $(0.017)$ & $(0.025)$ & $(0.023)$ & $(0.018)$ & $(0.025)$ & $(0.023)$ & $(0$ \\
\hline Con & $0.558^{* * * *}$ & 0.153 & $0.331 * * *$ & $0.558 * * *$ & 0.157 & $0.341^{* * *} *$ & $0.564 * * *$ & 0.156 & 0.3 \\
\hline & $(0.094)$ & $(0.102)$ & $(0.097)$ & $(0.094)$ & $(0.102)$ & $(0.096)$ & $(0.094)$ & $(0.102)$ & $(0$ \\
\hline Observations & 1,041 & 1,041 & 1,041 & 1,041 & 1,041 & 1,041 & 1,041 & 1,041 & 1 , \\
\hline R-squared & 0.633 & 0.595 & 0.757 & 0.633 & 0.595 & 0.759 & 0.633 & 0.596 & 0. \\
\hline AIC & -1171 & -927.1 & -1020 & -1169 & -925.1 & -1029 & -1168 & -926 & -1 \\
\hline $\mathrm{BIC}$ & -1127 & -882.5 & -975.1 & -1125 & -880.5 & -984.7 & -1124 & -881.4 & -9 \\
\hline Log-likelihood & 594.7 & 472.5 & 518.8 & 593.6 & 471.5 & 523.6 & 593 & 472 & 5 \\
\hline
\end{tabular}

$* * *$ p- value $<0.01, * *$ p-value $<0.05, *$ p-value $<0.10$. Standard error in parenthesis.

For these set of models, we estimated the Spatial Lag for the periods T1, T2 and T3. Overall, the results of these models corroborate that the Spatial Lag model with a temporal lag of one period presents the stronger effect of FMF. For the period 1992-1999, the positive coefficient of 0.650 that 
accompanies the variable FMF indicates that a 10\% increase in the migration flow brings as a result $6.5 \%$ increase in the urban expansion variable. When we reduce the temporal lags to half lag and no lag, the effect of forced migration on urban expansion dissipates with exception of the period T3=2007-2014, where the instantaneous effect of Flow Migration seems stronger (0.26 vs 0.19 in the half lag model and 0.086 in the one lag model). In all cases, the coefficient Rho for the Spatial Lag variable is positive and statistically significant at all conventional levels. This suggests a strong spatial interaction among neighboring municipalities in the process of urban expansion. As the urban expansion of neighboring municipalities increase, the urban expansion of an observed municipality also increases. Conversely, urban expansion in a determined municipality influences positively the urban expansion of the neighboring municipalities.

\subsection{Geographic weighted regression analysis}

We used a GWR model to analyze the spatial heterogeneity of the association between forced migration and anthropogenic expansion (ApSE). Since the best fit of the mentioned models was observed with one lag of FMF, we decided to focus on that one. The models were run using 5 different explanatory variables over ApSE: FMF, with one lag (to correct for endogeneity); demographic bonus; percentage of urban population; logarithm of the distance between each municipality and the departmental capital; and the municipality's percentage of deforested area since 2000. The following image shows the regions used for the analysis, and their correspondent AAC and ApSE values for each time period.

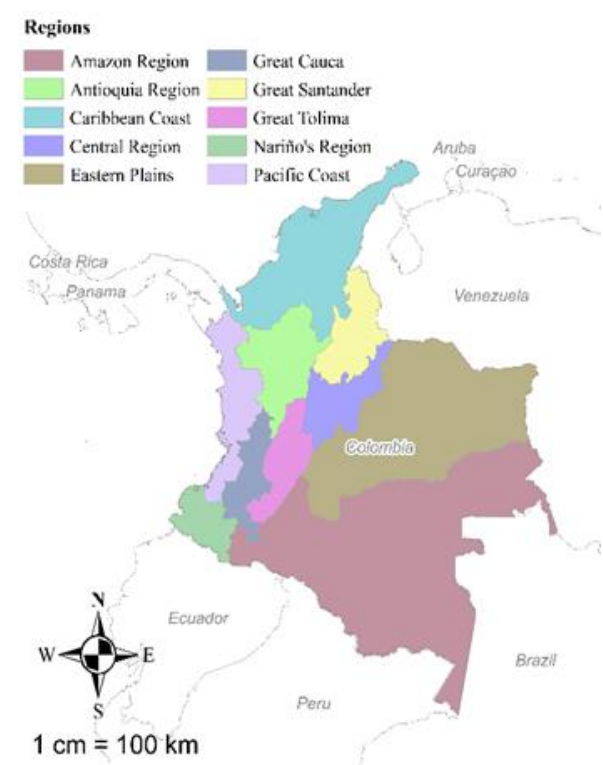

Figure 4: Regions of Colombia used in the Geographically Weighted Regression analysis

Table 4. Average AAC and ApSE per time period (T) 


\begin{tabular}{|c|c|c|c|c|c|c|}
\hline Region & & & & & & \\
\hline $\begin{array}{c}\text { Amazon } \\
\text { Region }\end{array}$ & $\begin{array}{c}\text { AAC } \\
\text { T1 }\end{array}$ & $\begin{array}{c}\text { AAC } \\
\text { T2 }\end{array}$ & $\begin{array}{c}\mathrm{AAC} \\
\mathrm{T} 2\end{array}$ & $\begin{array}{c}\text { ApSE } \\
\text { T1 }\end{array}$ & $\begin{array}{c}\text { ApSE } \\
\text { T2 }\end{array}$ & $\begin{array}{c}\text { ApSE } \\
\text { T3 }\end{array}$ \\
\hline $\begin{array}{l}\text { Antioqu } \\
\text { ia } \\
\text { Region }\end{array}$ & $-0,21$ & $-0,58$ & 1,43 & $3,1 \%$ & $21,2 \%$ & $17,0 \%$ \\
\hline $\begin{array}{l}\text { Caribbe } \\
\text { an } \\
\text { Coast }\end{array}$ & 0,33 & $-1,08$ & 2,08 & $15,8 \%$ & $49,8 \%$ & $38,5 \%$ \\
\hline $\begin{array}{l}\text { Central } \\
\text { Region }\end{array}$ & 0,61 & $-1,23$ & 2,42 & $19,2 \%$ & $47,9 \%$ & $38,4 \%$ \\
\hline $\begin{array}{l}\text { Eastern } \\
\text { Plains }\end{array}$ & 0,24 & $-0,88$ & 2,11 & $14,6 \%$ & $43,8 \%$ & $42,4 \%$ \\
\hline $\begin{array}{l}\text { Great } \\
\text { Cauca }\end{array}$ & 0,13 & $-0,76$ & 1,74 & $11,0 \%$ & $34,9 \%$ & $28,5 \%$ \\
\hline $\begin{array}{l}\text { Great } \\
\text { Santand } \\
\text { er }\end{array}$ & 0,55 & $-0,93$ & 2,10 & $19,9 \%$ & $36,7 \%$ & $37,7 \%$ \\
\hline $\begin{array}{l}\text { Great } \\
\text { Tolima }\end{array}$ & 0,53 & $-1,08$ & 2,33 & $22,4 \%$ & $44,7 \%$ & $47,3 \%$ \\
\hline $\begin{array}{l}\text { Nariño's } \\
\text { Region }\end{array}$ & 0,57 & $-0,87$ & 2,00 & $20,2 \%$ & $43,0 \%$ & $40,4 \%$ \\
\hline $\begin{array}{l}\text { Pacific } \\
\text { Coast }\end{array}$ & 0,66 & $-1,14$ & 2,52 & $24,6 \%$ & $46,2 \%$ & $51,5 \%$ \\
\hline $\begin{array}{l}\text { COLO } \\
\text { MBIA }\end{array}$ & 0,15 & $-0,76$ & 1,79 & $13,0 \%$ & $37,6 \%$ & $40,0 \%$ \\
\hline
\end{tabular}

Our estiamtes correspond to the independent variable FMF for each time period, and the intercepts coefficients and standard error for each model. The other mentioned reggressors' coefficients and standard errors were calculated as part of the models but are not shown. All the GWR models where run from a sample of 1,041 municipalities.

Figure 5. Effect of one lag FMF over the ApES from 1992 to 1999.

The effect of one lag FMF over the ApES from 1992 to 1999

\section{GWR rusults}

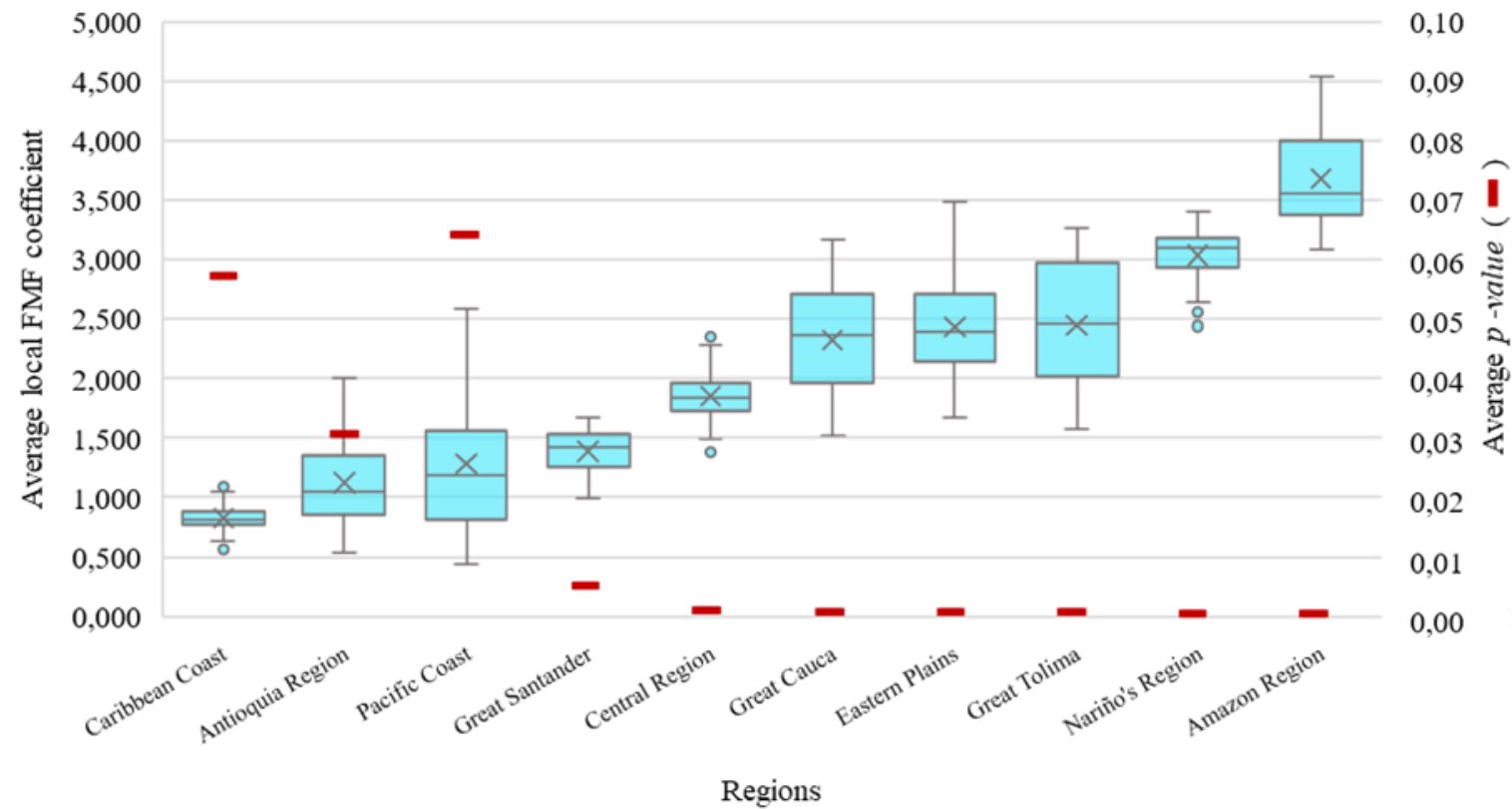


Figure 5 shows the distribution of the coefficient of the FMF between 1984 and 1991 over the ApSE from 1992 to 1999. The graph shows the relationship between FMF from the 1980's and the ApSE in the 1990 's, differentiated by region. Note that the effect violence from the 80 's (drug traffickingviolence), had significant effect over the configuration of the anthropogenic print in the 90's in all the regions ( $p$-value $<0.1$ ). Some of these regions' anthropogenic prints had a much higher sensitivity towards violence than others. For example, in the Eastern Plains and the Great Tolima regions, the effect of violence on the ApSE was almost 2,2 times higher than in the Antioquia region (where cities like Medellin, Pereira or Armenia are located).

Also, we found that AsPE in the 1990's of both the Pacific and Caribbean costs had less relationships with FMF than that of inland territories and thus, there seems to be a periphery-center behavior with respect to violence and urban expansion. A possible explanation is that as violence was stronger in these regions, they could be categorized as sources of migration, while other regions were receiving (sinks).

Table 5. GWR: One lag model over ApSE from 1992 to 1999 (T1)

\begin{tabular}{lccccc}
\hline Regions & $\begin{array}{c}\text { Avg Local } \\
\text { R2 }\end{array}$ & $\begin{array}{c}\text { Interce } \\
\text { pt }\end{array}$ & Intercept's Std Error & $\begin{array}{c}\text { FMF's } \\
\text { Coefficient }\end{array}$ & $\begin{array}{r}\text { FMF's } \\
\text { value }\end{array}$ \\
\hline Amazon Region & 0,308 & 0,484 & 0,065 & 3,678 & 0,000 \\
Nariño's Region & 0,350 & 0,652 & 0,063 & 3,033 & 0,000 \\
Great Tolima & 0,353 & 0,707 & 0,063 & 2,450 & 0,000 \\
Eastern Plains & 0,312 & 0,605 & 0,070 & 2,436 & 0,000 \\
Great Cauca & 0,362 & 0,695 & 0,061 & 2,323 & 0,000 \\
Central Region & 0,338 & 0,687 & 0,069 & 1,851 & 0,001 \\
Great Santander & 0,323 & 0,593 & 0,068 & 1,385 & 0,005 \\
Pacific Coast & 0,394 & 0,699 & 0,069 & 1,283 & 0,065 \\
Antioquia & 0,380 & 0,703 & 0,068 & 1,121 & 0,031 \\
Region & 0,392 & 0,555 & 0,065 & 0,824 & 0,058 \\
Caribbean Coast & & & & &
\end{tabular}

The Nariño and Amazon regions, show the effect of the FMF over the ApSE were signify higher than the rest of the country ( $p$-value $<0.01$ ). Since we did not carry out a categorization AsPE types, we can only suspect that observed coefficients in these regions correspond to the expansion of illegal mining and illicit corps over the time period. Further research and analysis are needed to support or reject this hypothesis. 
The effect of one lag FMF over the ApES from 2000 to 2008 GWR rusults

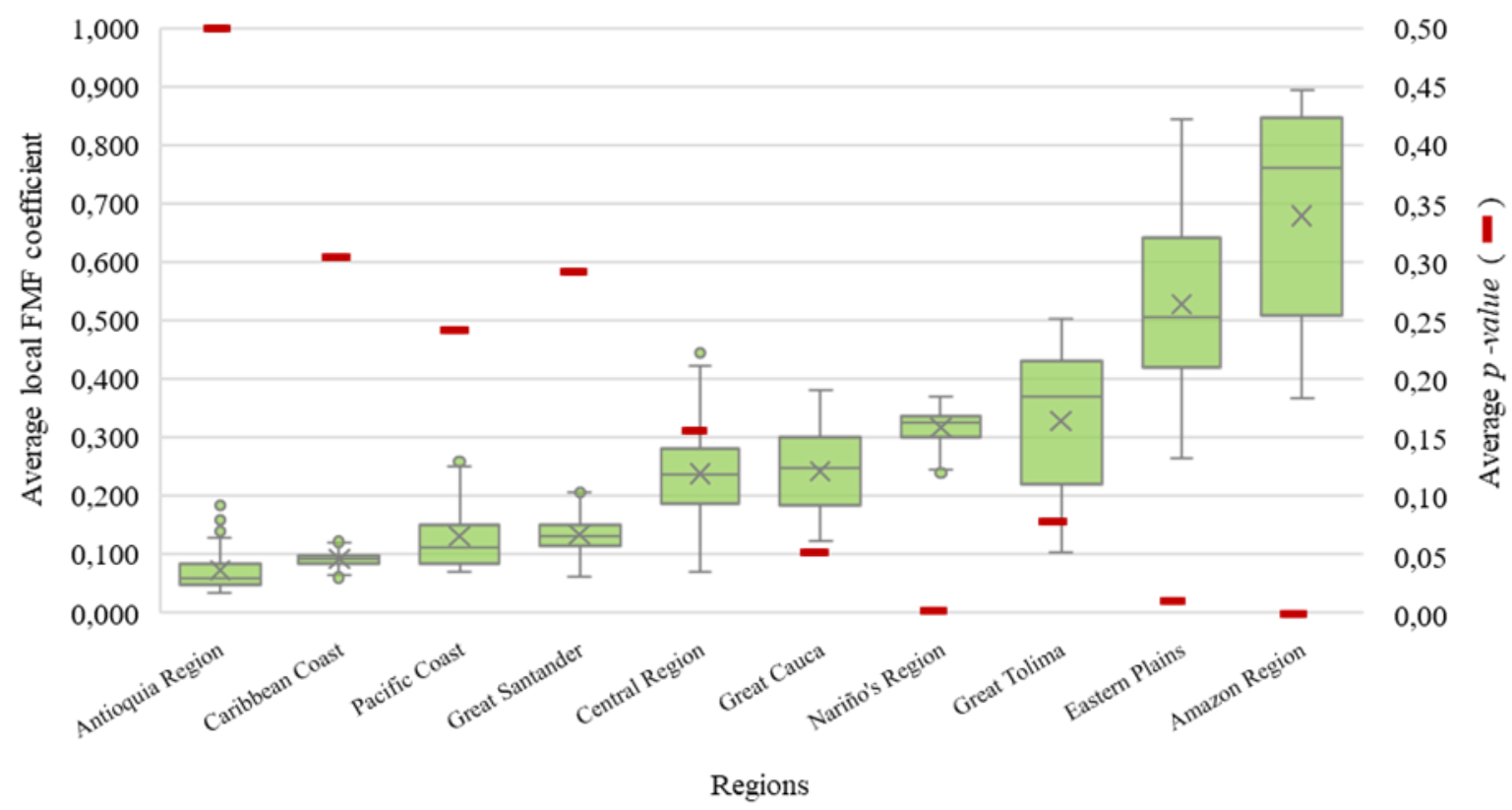

Figure 6. Effect of one lag FMF over the ApES from 2000 to 2008.

Figure 6 shows the relationship between FMF from the 1980s and the ApSE form the 1990s, when looking to the relation between forced migration in the 1990s and the ApSE from between 2000 and 2008, there several key differences. Most noticable is the loss of FMF's significance in five of the 10 regions marked. This does not suggest that in these regions there was no expansion of the anthropogenic print (in fact, the Antioquia Region experienced the largest proportional expansion) or forced migration, but rather, according to our data and analyses, there seems to be no significant relationship between these two variables for half of the regions within this period of time.

Table 6. GWR: One lag model over ApSE from 2000 to 2007 (T2)

\begin{tabular}{lccccc}
\hline Regions & $\begin{array}{c}\text { Avg Local } \\
\mathrm{R} 2\end{array}$ & $\begin{array}{c}\text { Interce } \\
\mathrm{pt}\end{array}$ & $\begin{array}{c}\text { Intercept's Std Error } \\
\text { Coefficient }\end{array}$ & $\begin{array}{r}\text { FMF's, } \\
\text { value }\end{array}$ \\
\hline Amazon Region & 0,125 & 0,427 & 0,075 & 0,678 & 0,002 \\
Antioquia & 0,162 & 0,899 & 0,078 & 0,072 & 0,496 \\
Region & 0,227 & 0,902 & 0,075 & 0,092 & 0,303 \\
Caribbean Coast & 0,132 & 0,802 & 0,079 & 0,238 & 0,157 \\
Central Region & 0,118 & 0,661 & 0,080 & 0,528 & 0,013 \\
Eastern Plains & 0,101 & 0,562 & 0,071 & 0,242 & 0,054 \\
Great Cauca & 0,168 & 0,853 & 0,078 & 0,134 & 0,291 \\
Great Santander & 0,104 & 0,626 & 0,072 & 0,329 & 0,079 \\
Great Tolima & 0,104 & 0,434 & 0,073 & 0,316 & 0,005 \\
Nariño's Region & 0,143 & 0,768 & 0,079 & 0,131 & 0,241 \\
Pacific Coast & & & & &
\end{tabular}

The loss of significance of FMF effect over the anthropogenic print was observed for both Antioquia and the central region. This does not mean that they did not experience spatial expansion of the anthropogenic print, in fact they were also among the regions the largest spatial change in the country over that period (Table 4). We hypothesize, though further research is needed, that rural 
to urban migrations was not related with violence, but with rural poverty and conditions of living, and it rendered the effect of FMF insignificant. Another factor that could affect this estimate is the anthropogenic print expansion's morphology: Porous or spongy urban areas and peripheries, could led to densification process that are hard to identify by the type of information used. Nevertheless, this data could open a debate around the identification of other key drivers of the expansion of the city and the human activity in Colombia's landscape.

The effect of one lag FMF over the ApES from 2007 to 2014 GWR rusults

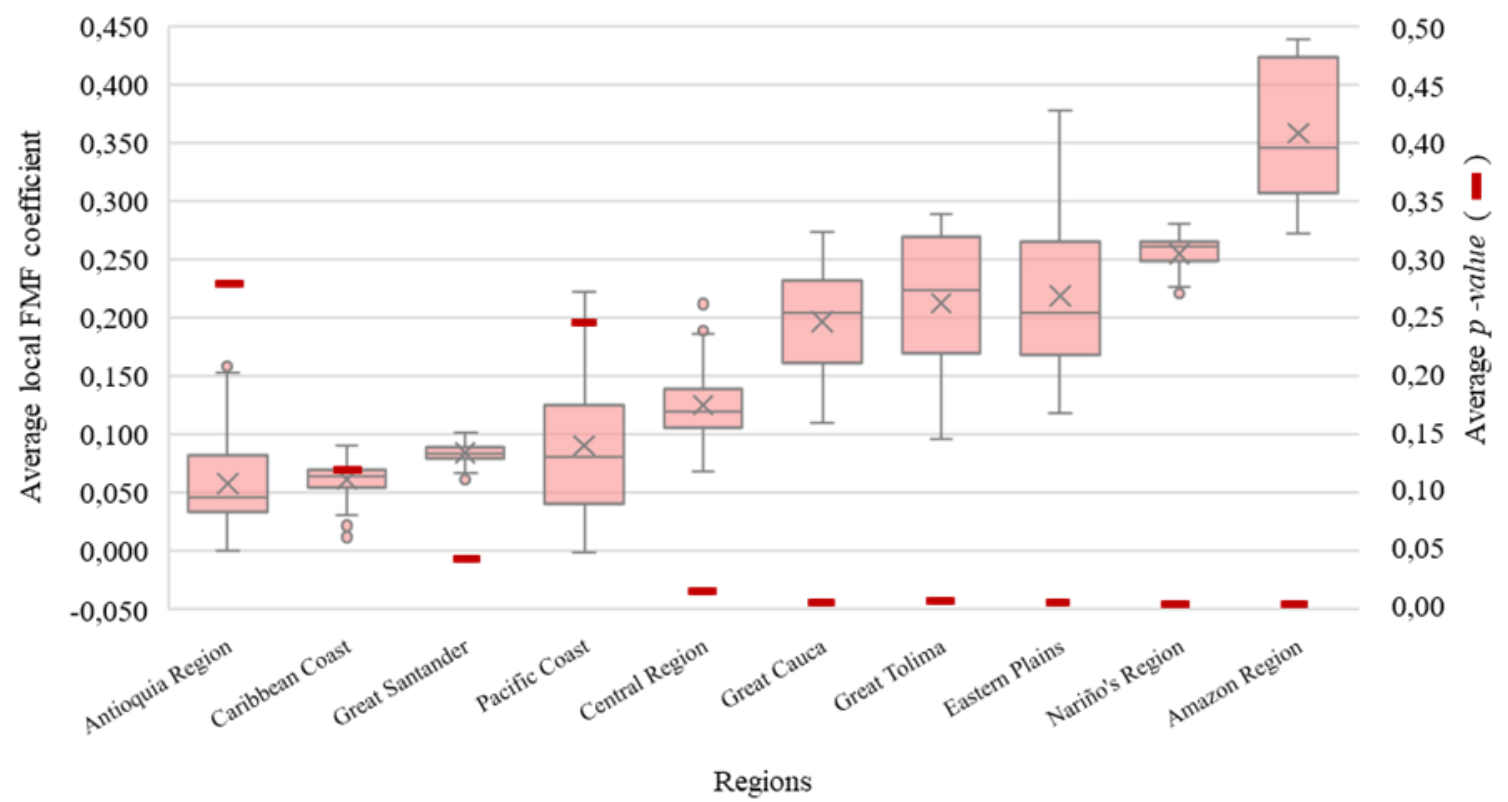

Figure 7. Effect of one lag FMF over the ApES from 2007 to 2014.

The relationship between FMF and ApSE over the last time period shows that FMF recovers predictive ability towards anthropogenic change compared with $\mathrm{T} 2$. This suggests that the expansion of the anthropogenic print between 2000 and 2007 follows a different trend with respect to the ApSE between 1992 and 1999, and the ApSE between 2007 and 2014. The political history associated with each of these time periods provides the context to understand such changes, since T2 is both the peak of FMF and coincides with one of the most controversial political events during this analysis period; a public policy by a right-wing government whose aim was to recover security. T1, on the contrary, is associated with a context of violence due to drug-trafficking. 
Table 7. GWR: One lag model over ApSE from 2008 to 2014 (T3)

\begin{tabular}{|c|c|c|c|c|c|}
\hline Regions & $\begin{array}{c}\text { Avg Local } \\
\text { R2 }\end{array}$ & $\begin{array}{c}\text { Interce } \\
\mathrm{pt}\end{array}$ & Intercept's Std Error & $\begin{array}{c}\text { FMF's } \\
\text { Coefficient }\end{array}$ & $\begin{array}{r}\text { FMF's } \\
\text { value }\end{array}$ \\
\hline Amazon Region & 0,235 & 0,665 & 0,085 & 0,358 & 0,000 \\
\hline $\begin{array}{l}\text { Antioquia } \\
\text { Region }\end{array}$ & 0,322 & 1,303 & 0,087 & 0,058 & 0,274 \\
\hline Caribbean Coast & 0,369 & 1,161 & 0,085 & 0,061 & 0,114 \\
\hline Central Region & 0,271 & 1,181 & 0,088 & 0,125 & 0,010 \\
\hline Eastern Plains & 0,239 & 1,004 & 0,089 & 0,219 & 0,001 \\
\hline Great Cauca & 0,248 & 0,969 & 0,079 & 0,197 & 0,000 \\
\hline Great Santander & 0,313 & 1,223 & 0,087 & 0,084 & 0,038 \\
\hline Great Tolima & 0,245 & 1,000 & 0,081 & 0,213 & 0,002 \\
\hline Nariño's Region & 0,244 & 0,830 & 0,082 & 0,255 & 0,000 \\
\hline Pacific Coast & 0,308 & 1,198 & 0,088 & 0,091 & 0,240 \\
\hline
\end{tabular}

Finally, we also analyzed the effect of one lag of FMF on the ApSE of the seven biggest metropolitan areas (MA) in the country: Bogota, Aburra Valley, Cali, Barranquilla, Cartagena, Bucaramanga and Cucuta. Overall, more than 20.2 million people live in these areas, accounting for $45 \%$ of Colombia's censed population (CENSO 2019, preliminary data). Results are shown in Figure 8, and suggest there is little effect of FMF on ApSE in MAs, or not adequately captured by our model, particularly during T2. T1 is significant and shows a positive effect with coefficients above 0.5 for most MAs (larger for those close to Venezuela) except in the Aburra Valley (Medellin) MA. This confirms the observed regional effect in previous models.

\section{The effect of one lag FMF over the ApES of metropolitan areas arobe one millon population GWR rusults}

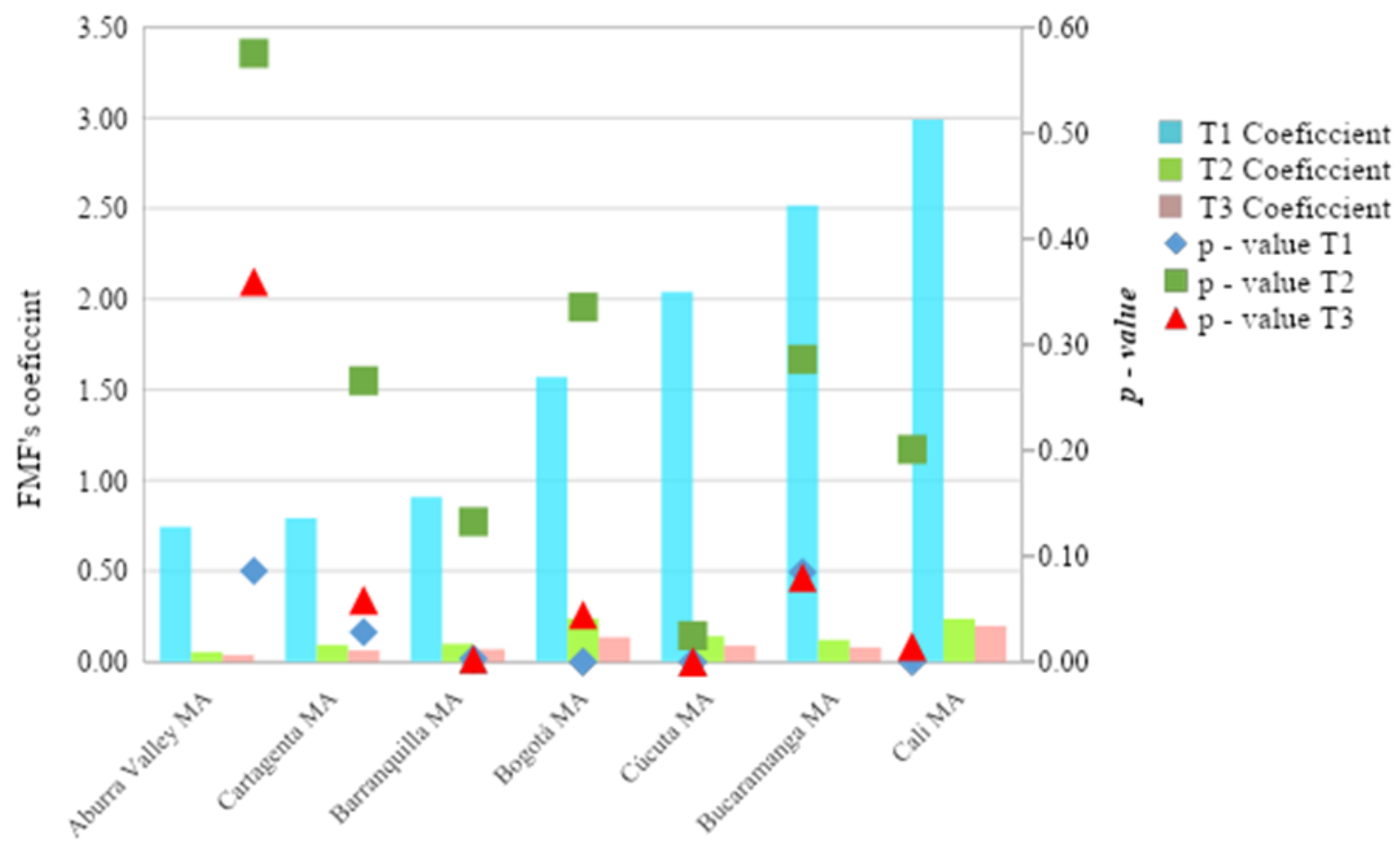

Figure 8. Effect of one lag FMF over ApES of metropolitan areas above one million inhabitants. 


\section{Discussion}

Our findings are consistent with other studies [67-69]. First, we find that both migration and demographic change play an important role in urban growth, and most interestingly, we find that these roles can change in importance in terms of explaining potential spatial patterns such as urban sprawl. We found that internal migration over the period 2000-2007 was more influential in explaining urbanization, than in previous periods. However, we did find evidence that population structure is strongly associated with urban growth over periods of less intense forced migration. This increase in rural - urban migration observed during 2000-2007 rendered structural characteristics of the population less important in terms of urbanization. This finding has strong implications in terms of the importance between migration and vital rates in the demographic transition. However, we have observed that their importance can vary across specific decades (which is a short time in terms of demographic transitions).

Another finding was the relationship between areas receiving IDPs and their rates of deforestation [7] . Carrillo [72](2009) suggests that the precarious conditions of some IDPs arrive in not only peri-urban but rural areas where they participate in activities such as logging, illegal crops or cattle ranching, that lead to land use-land cover changes and deforestation, similar to what is reported by several authors [73]. In particular, certain illegal activities such as illegal drug cultivation and mining are key activities in which IDPs participate [74]. As such, the migration paths taken by IDPs are not strictly rural-urban but also rural-rural migration. This takes place both in the receiving and expelling areas, but is more significant in the former given the population density. Overall, studies on forced migration document how IDPs experience a substantial decrease in overall well-being. Such internally displaced households also experience considerable drops in aggregate consumption per adult equivalent [8]. Only access to state services and infrastructure and a strong institutional presence contribute to mitigating the incidence of IDPs [25].

\subsection{Limitations}

Our study has potential limitations. First, we are inferring the anthropogenic print from nighttime satellite imagery, which is only one of many methods used to study urban growth. Further studies with other image collections will probably increase our understanding of the relationship between these variables (migration and urban growth), with greater heterogeneity and resolution. Our migration dataset was also composed of aggregated values. As better information becomes available over the routes of individuals over space and time, these processes will also be better understood. As mobile phone data, for example, becomes available to describe mobility patterns of migrant populations, we will also be able to associate specific migrant profiles to spatial patterns. Our study, however, lays forward a set of questions that can be better framed after this exploratory study.

\section{Conclusions}

Internal migrations, due to armed conflicts, have affected the social fabric of many nations [70]. In Colombia, we found that the migration of IDPs has not directly impacted the larger urban centers (Figure 8). In particular, this rural-urban migration has substantially impacted peri-urban, rather than inner urban areas, and this has important implications given their lower response capacity, lack of infrastructure and resilience [21]. However, migration due to violence does not have a static logic. That is, the flows vary according to different contexts such as violence and the demographic transition of the local population, which makes formulation of public policies aimed at dealing with the effects of IDPs migrating to cities very complex (See figure 1). 
The problems associated with displaced persons and their migration are not exclusive to the periurban and urban areas that are receiving them, although these are the areas and IDP that require the most assistance [71]. Similarly, sources of IDPs also undergo particular detrimental dynamics such as reduced economic activity and increased deforestation due to urban and rural land abandonment [8] . Hence, it is important to address the problems of IDPs in both expelling and receiving areas.

Author Contributions: All authors have read and agree to the published version of the manuscript. Conceptualization, A.S. and A.P.; methodology, A.F-R. and F.C.; software, A.F-R., F.C. and G.C..; validation, F.E. and A.F-R..; formal analysis, A.S., A.P. and A.F-R.; investigation, A.F-R..; resources, A.F-R and G.C..; data curation, F.C., G.C. and A. F-R..; writing-original draft preparation, A.S. and A.P..; writing-review and editing, A.S., A.P. and F.E..; visualization, F.C. and G.C..; supervision, F.C. and A.F-R..; project administration, A.S.

Funding: This research received no external funding.

Conflicts of Interest: The authors declare no conflict of interest.

References

1. Kalnay, E.; Cai, M. Impact of urbanization and land-use change on climate. Nature 2003, 423, 528-531.

2. Creutzig, F.; Baiocchi, G.; Bierkandt, R.; Pichler, P.-P.; Seto, K.C. Global typology of urban energy use and potentials for an urbanization mitigation wedge. PNAS 2015, 112, 62836288.

3. Kasman, A.; Duman, Y.S. CO2 emissions, economic growth, energy consumption, trade and urbanization in new EU member and candidate countries: A panel data analysis. Economic Modelling 2015, 44, 97-103.

4. McKinney, M.L. Urbanization, Biodiversity, and ConservationThe impacts of urbanization on native species are poorly studied, but educating a highly urbanized human population about these impacts can greatly improve species conservation in all ecosystems. Bioscience 2002, 52, 883-890.

5. Aronson Myla F. J.; La Sorte Frank A.; Nilon Charles H.; Katti Madhusudan; Goddard Mark A.; Lepczyk Christopher A.; Warren Paige S.; Williams Nicholas S. G.; Cilliers Sarel; Clarkson Bruce; et al. A global analysis of the impacts of urbanization on bird and plant diversity reveals key anthropogenic drivers. Proceedings of the Royal Society B: Biological Sciences 2014, 281, 20133330.

6. Ogden, L.A. The Beaver DiasporaA Thought Experiment. Environmental Humanities 2018, $10,63-85$.

7. He, C.; Chen, T.; Mao, X.; Zhou, Y. Economic transition, urbanization and population redistribution in China. Habitat International 2016, 39-47.

8. Ibáñez, A.M.; Moya, A.; others Cómo el desplazamiento forzado deteriora el bienestar de los hogares desplazados?: análisis y determinantes del bienestar en los municipios de recepción; CEDE, 2006;

9. Gollin, D.; Jedwab, R.; Vollrath, D. Urbanization with and without industrialization. J Econ Growth 2016, 21, 35-70. 
10. Chauvin, J.P.; Glaeser, E.; Ma, Y.; Tobio, K. What is different about urbanization in rich and poor countries? Cities in Brazil, China, India and the United States. Journal of Urban Economics 2017, 98, 17-49.

11. Hamdani, K. Trans-border Vulnerabilities. Human Development Research Paper. United Nations Development Programme, Human Development Report Office, New York 2014.

12. Raleigh, $C$. The search for safety: The effects of conflict, poverty and ecological influences on migration in the developing world. Global Environmental Change 2011, 21, S82-S93.

13. Bakewell, O. Conceptualising Displacement and migration: Processes, conditions, and categories. The migration-displacement nexus: Patterns, processes, and policies. Oxford: Berghahn Books 2011, 14-28.

14. Hathaway, J.C. Forced Migration Studies: Could We Agree Just to 'Date'? Journal of Refugee Studies 2007, 20, 349-369.

15. Bennett, J. Forced migration within national borders: the IDP agenda. Forced Migration Review 1998, 1998, 4-6.

16. Weiss, T.G.; Korn, D.A. Internal displacement: conceptualization and its consequences; Routledge, 2006;

17. Zetter, R. More labels, fewer refugees: Remaking the refugee label in an era of globalization. Journal of refugee studies 2007, 20, 172-192.

18. Council, N.R. Global Overview 2015. People internally displaced by conflict and violence; Ginebra: Internal Displacement Monitoring Centre. Consultado en: http://www ..., 2015;

19. Castles, S. Towards a sociology of forced migration and social transformation. Sociology 2003, 37, 13-34.

20. sentencia t 8322014 corte constitucional - Google Search Available online: https://www.google.com/search?q=sentencia+t+832+2014+corte+constitucional\&rlz=1C5C HFA_enC0869C0869\&oq=sentencia+t+832+2014+corte+constitucional\&aqs=chrome..69i5 7j69i60.783j0j9\&sourceid=chrome\&ie=UTF-8 (accessed on Dec 17, 2019).

21. Ibáñez, A.M.; Velásquez, A. El impacto del desplazamiento forzoso en Colombia: condiciones socioeconómicas de la población desplazada, vinculación a los mercados laborales y políticas públicas; CEPAL, 2008;

22. Ibáñez, A.M. El desplazamiento forzoso en Colombia: un camino sin retorno hacia la pobreza; Ediciones Uniandes-Universidad de los Andes, 2008;

23. Balcells, L.; Steele, A. Warfare, political identities, and displacement in Spain and Colombia. Political Geography 2016, 51, 15-29.

24. Kalyvas, S.N. La lógica de la violencia en la guerra civil; Ediciones Akal, 2010; Vol. 299;.

25. Ibáñez, A.M. Génesis del desplazamiento forzoso en Colombia: sus orígenes, sus consecuencias y el problema del retorno. 2004.

26. Escobar, A. Desplazamientos, desarrollo y modernidad en el Pacífico colombiano. Conflicto e (in) visibilidad. Retos en los estudios de la gente negra en Colombia 2004, 53-72.

27. Aguilera Peña, M. Las FARC: la guerrilla campesina, 1949-2010?’ Ideas circulares en un mundo cambiante?; Organización Internacional para las Migraciones (OIM-Misión Colombia), 2016;

28. Sánchez, G.; Peñaranda, R. Pasado y presente de la violencia en Colombia. Historia contemporanea 1986. 
29. Mackenzie, E. Las FARC: el fracaso de un terrorismo; Mondadori, Debate, 2007;

30. González, F.E.G. Poder y violencia en Colombia; Edtitorial Pontificia Universidad Javeriana, 2014; ISBN 978-958-644-201-5.

31. Leongómez, E.P. Las FARC (1949-2011): de guerrilla campesina a máquina de guerra; Grupo Editorial Norma, 2011;

32. Sierra, J.R. Breve historia del conflicto armado en Colombia; Los Libros de la Catarata, 2019;

33. Villamizar Herrera, D. Las guerrillas en Colombia: una historia desde los orígenes hasta los confines; Random House, Bogotá, 2017;

34. Cinep The Legacy of Uribe Policies: challenges for the Santos administration Available online:

https://issuu.com/cinepppp/docs/the_legacy_of_uribe_policies_specialr_august2010 (accessed on Dec 17, 2019).

35. Patino, J.E.; Duque, J.C. A review of regional science applications of satellite remote sensing in urban settings. Computers, Environment and Urban Systems 2013, 37, 1-17.

36. Lo, C.P.; Faber, B.J. Integration of Landsat Thematic Mapper and census data for quality of life assessment. Remote sensing of environment 1997, 62, 143-157.

37. Green, N.E. Aerial photographic interpretation and the social structure of the city; American Society of Photogrammetry, 1957;

38. Monier, R.B.; Green, N.E. Aerial photographic interpretation and the human geography of the city. The Professional Geographer 1957, 9, 2-5.

39. Metivier, E.; McCoy, R. Mapping urban poverty housing from aerial photographs. In Proceedings of the Proceedings of the Seventh International Symposium on Remote Sensing of Environment, Ann Arbor: University of Michigan Press; 1971; Vol. 15631569.

40. Mumbower, L.E.; Donoghue, J. Urban poverty study. Photogrammetric Engineering 1967, 33, 610-618.

41. WEBER, C.; HIRSCH, J. Some urban measurements from SPOT data: urban life quality indices. International Journal of Remote Sensing 1992, 13, 3251-3261.

42. Mullens Jr, R.H.; Senger, L.W. Analysis of urban residential environments using color infrared aerial photography: An examination of socioeconomic variables and physical characteristics of selected areas in the Los Angeles basin, with addendum: An application of the concepts of the Los Angeles residential environment study to the Ontario-Upland region of California. 1969.

43. Miller, P.R.; Winer, A.M. Composition and dominance in Los Angeles Basin urban vegetation. Urban Ecology 1984, 8, 29-54.

44. Phinn, S.; Stanford, M.; Scarth, P.; Murray, A.; Shyy, P. Monitoring the composition of urban environments based on the vegetation-impervious surface-soil (VIS) model by subpixel analysis techniques. International Journal of Remote Sensing 2002, 23, 41314153.

45. Griffiths, P.; Hostert, P.; Gruebner, O.; van der Linden, S. Mapping megacity growth with multi-sensor data. Remote Sensing of Environment 2010, 114, 426-439.

46. Lu, D.; Weng, Q. Spectral mixture analysis of the urban landscape in Indianapolis with Landsat ETM+ imagery. Photogrammetric Engineering \& Remote Sensing 2004, 70, 10531062. 
47. Rashed, T.; Weeks, J.R.; Gadalla, M.S.; Hill, A.G. Revealing the anatomy of cities through spectral mixture analysis of multispectral satellite imagery: a case study of the Greater Cairo region, Egypt. Geocarto International 2001, 16, 7-18.

48. Taubenböck, H.; Wegmann, M.; Roth, A.; Mehl, H.; Dech, S. Urbanization in IndiaSpatiotemporal analysis using remote sensing data. Computers, environment and urban systems 2009, 33, 179-188.

49. Yin, Z.-Y.; Stewart, D.J.; Bullard, S.; MacLachlan, J.T. Changes in urban built-up surface and population distribution patterns during 1986-1999: A case study of Cairo, Egypt. Computers, Environment and Urban Systems 2005, 29, 595-616.

50. Ma, T.; Zhou, Y.; Zhou, C.; Haynie, S.; Pei, T.; Xu, T. Night-time light derived estimation of spatio-temporal characteristics of urbanization dynamics using DMSP/OLS satellite data. Remote Sensing of Environment 2015, 158, 453-464.

51. Xie, Y.; Weng, Q. Detecting urban-scale dynamics of electricity consumption at Chinese cities using time-series DMSP-OLS (Defense Meteorological Satellite Program-Operational Linescan System) nighttime light imageries. Energy 2016, 100, 177-189.

52. Xiao, H.; Ma, Z.; Mi, Z.; Kelsey, J.; Zheng, J.; Yin, W.; Yan, M. Spatio-temporal simulation of energy consumption in China's provinces based on satellite night-time light data. Applied Energy 2018, 231, 1070-1078.

53. Sutton, P. Modeling population density with night-time satellite imagery and GIS. Computers, Environment and Urban Systems 1997, 21, 227-244.

54. Mellander, C.; Lobo, J.; Stolarick, K.; Matheson, Z. Night-time light data: A good proxy measure for economic activity? PloS one 2015, 10, e0139779.

55. Witmer, F.D. Remote sensing of violent conflict: Eyes from above. International Journal of Remote Sensing 2015, 36, 2326-2352.

56. Abu-Lughod, J.; Hay, R.J. Third world urbanization; Routledge, 2013;

57. Bertinelli, L.; Black, D. Urbanization and growth. Journal of Urban Economics 2004, 56, 8096.

58. Tao, R.; Xu, Z. Urbanization, rural land system and social security for migrants in China. The Journal of Development Studies 2007, 43, 1301-1320.

59. Ocampo, J. El Campo Colombiano: un camino hacia el bienestar y la paz. Departaménto de Planeación Nacionlal (DNP): Misión para la transformación del campo 2015.

60. Kelejian, H.; Piras, G. Spatial econometrics; Academic Press, 2017;

61. Ord, K. Estimation methods for models of spatial interaction. Journal of the American Statistical Association 1975, 70, 120-126.

62. Elhorst, J.P. Applied spatial econometrics: raising the bar. Spatial economic analysis 2010, 5, 9-28.

63. Anselin, L. Spatial externalities, spatial multipliers, and spatial econometrics. International regional science review 2003, 26, 153-166.

64. Beenstock, M.; Felsenstein, D. The Econometric Analysis of Non-Stationary Spatial Panel Data; Springer, 2019;

65. Brunsdon, C.; Fotheringham, S.; Charlton, M. Geographically weighted regression. Journal of the Royal Statistical Society: Series D (The Statistician) 1998, 47, 431-443. 
66. Fotheringham, A.S.; Brunsdon, C.; Charlton, M. Geographically weighted regression: the analysis of spatially varying relationships; John Wiley \& Sons, 2003;

67. Williamson, J.G. Migration and urbanization. Handbook of development economics 1988, 1, 425-465.

68. Zhang, K.H.; Shunfeng, S. Rural-urban migration and urbanization in China: Evidence from time-series and cross-section analyses. China Economic Review 2003, 14, 386-400.

69. Green, L. Migration, urbanization, and national development in Nigeria. In Modern Migrations in Western Africa; Routledge, 2018; pp. 281-304.

70. Leighton, M. Desertification and migration. In Governing global desertification; Routledge, 2016; pp. 63-78.

71. Landau, L.B. Displacement and the pursuit of urban protection: Forced migration, fluidity and global cities. In Forced Migration; Routledge, 2018; pp. 106-125.

72. Carrillo, A.C. Internal displacement in Colombia: humanitarian, economic and social consequences in urban settings and current challenges. International Review of the Red Cross 2009, 91, 527-546.

73. Alix-Garcia, J.; Bartlett, A.; Saah, D. The landscape of conflict: IDPs, aid and land-use change in Darfur. Journal of Economic Geography 2013, 13, 589-617.

74. Angrist, J.D.; Kugler, A.D. Rural windfall or a new resource curse? Coca, income, and civil conflict in Colombia. The Review of Economics and Statistics 2008, 90, 191-215. 